INVITED ARTICLE

Participatory Educational Research (PER)

Vol. 1(2), pp. 106-132, December, 2014

Available online at http://www.partedres.com

ISSN: $2148-6123$

http://dx.doi.org/10.17275/per.14.14.1.2

\title{
Participatory Approach to Education: an Action Learning Approach at the University of South Africa
}

\author{
Janet McIntyre-Mills* \\ Flinders University, University of Indonesia, University of Islamic Studies, \\ Gladys Mokwena Kedibone \\ University of South Africa, South Africa
}

Akwasi Arko-Achemfuor

University of South Africa, South Africa

Pinkie Mabunda

University of South Africa, South Africa

Esther Njiro

University of South Africa, South Africa

Article history

Received:

27.10.2014

Received in revised form: 07.11.2014

Accepted:

09.11.2014

Key words:

participatory action research, action learning, community of practice
The paper discusses a critical systemic thinking and practice approach to building capacity, enhancing development and addressing public policy and governance concerns through holding in mind many variables and considering the areas of concern of the facilitator and the participants. Inspiration for the approach to learning drew on a range of sources including Bateson on 'the ecology of mind' (1972), Paulo Freire (1982, 2007) on action learning and Checkland and Scholes (1990) for soft systems mapping to address an area of concern with a small group of researchers who are dedicated to working outside the boundaries of a contained discipline or organization in the service of a broad learning community. The participants raised the following as research concerns: unemployment, recognition of prior learning and the need to enhance pathways for adults and young people in learning organisations and learning communities that are responsive to the complex needs of South Africans and those within the wider region. An open approach to education and respecting diverse ways of knowing is a starting point for people's education and community development. The struggle in South Africa for transformation was typified by student protests during Apartheid for the right to a free and equal education system. At UNISA we are reminded of the need to use education as a means to empower and this means beginning with the lived experiences of people.

\footnotetext{
Correspondence: Janet.mcintyre@flinders.edu.au
} 


\section{Introduction}

A workshop was held at the Department of Adult Basic Education and Training and Youth Development on the 28 July at the University of South Africa (UNISA). UNISA is a distance learning university that has transformed from protest during the Apartheid era of education to policy that respects prior learning and indigenous knowledge.

The aim of the workshop was to demonstrate the participatory approach to action learning with graduates and staff through engaging in a round table research conversation that I was invited to facilitate by ABET and Youth Development staff and a colleague from the School of Teacher Education.

\section{An 'ecology of mind' for participatory action learning, design and praxis}

An 'ecology of mind' (Bateson, 1972) means thinking about thinking through moving from approaching an area of concern with just level 1 learning from one set of lenses or one paradigm to moving to level 2 learning with involves comparing and contrasting approaches from different experiences and with insights from different disciplines to then developing a level 3 learning approach that involves co-creating, transforming or being innovative. The process involved participants reflecting on their own areas of concern using an adapted 'Design of Inquiring Systems Approach' (drawing also on Kenneth Bausch, Capra, West Churchman, Alexander Christakis, Stuart Hall, Paulo Freire and Checkland and Scholes) for inspiration to foster an ecology of mind and open, critical approach to mapping an area of concern by considering the implications of thinking for practice and implementation.

\section{Participatory Action Research and Action Learning Process and Methodology- Pooling Experience, Questioning and the Dialectic}

Five participants engaged in a research conversation to explore areas of concern and to co-create an understanding of research priorities and research directions for ABET and Youth Development. The action learning process involved a systemic approach where facilitation and two-way learning were modelled by sitting in a circle and facilitating a conversation that drew on each participant's lived experiences. The starting point is a recognition that people identify with learning processes that are meaningful and relevant to their own areas of concern. I shared my own concerns about complex challenges associated with climate change and the implications for food, energy and water within and beyond the boundaries of the nation state. I explained that Joseph Stiglitz (previous chief economist of the World Bank) visited Australia at the invitation of the Productivity Commission in 2010 and that he stressed the need for nation states to re-consider what they value and why. This has led me to develop research on pathways to wellbeing to reframe the notion of economics to consider that the economic bottom line of profit needs to be replaced with a more systemic approach that goes beyond the raft of indicators mentioned in "Mis-measuring our lives" to consider alternative ways of being, doing, having and interacting based on the work of Max Neef (1991).

Thus the conversation began with an introduction of my own interests and research passions and then a request for the participants to express their own concerns and to pool resources to assist 
them to address their own research tasks. A community of practice means a network of people who agree to work together to address a shared area of concern and to give and receive assistance to one another, in order to achieve the identified tasks. I invited the research conversation participants to:

- Think about how they could use their own prior learning to inform their area of concern for research. The idea is to apply PAR to learning with participants so that learning builds on what we already know. The creative energy of learning together creates an environment of creativity that fosters learning.

- Engage in considering their own areas of concern and suggested that we strive to consider each strand of experience and that perhaps we could co-create meaning as a result of weaving together the strands of experience in conversation.

Participants focused on their specific areas of concern and questions with the following process:

- Each participant was asked to discuss their own area of concern for research. As facilitator I modelled the process by first explaining my own area of concern for developing transdisciplinary approaches to research and practice and mapped some of the ideas on a white board whilst I shared my broad research interests as a precursor to listening to each of the participants own interests and concerns I linked my lenses with my area of policy concern with What? Who? Why? How? and So what questions? For example: what models exist for developing alternative pathways to learning? How could these be implemented? What are the possibilities for undertaking a pilot action learning and PAR project to demonstrate ways of developing partnerships within and beyond the boundaries of UNISA with the community and a range of public, NGO and government organisations to foster a learning community approach to capacity building?

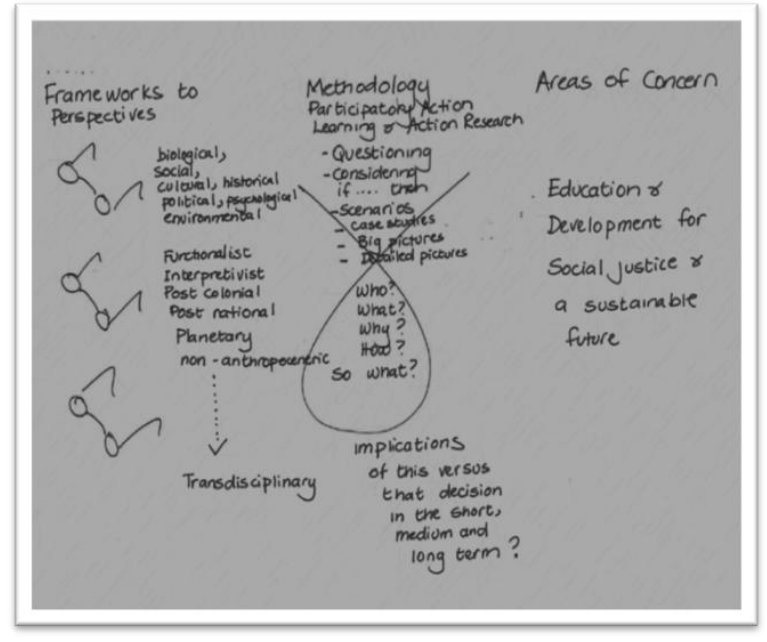

Figure 1: Methodology and Area of concern (FMA approach) approach to my own area of concern

- Then I asked participants to reflect on their concerns using the following conceptual map 
(drawing in Checkland and Scholes) :

\section{FMA approach}

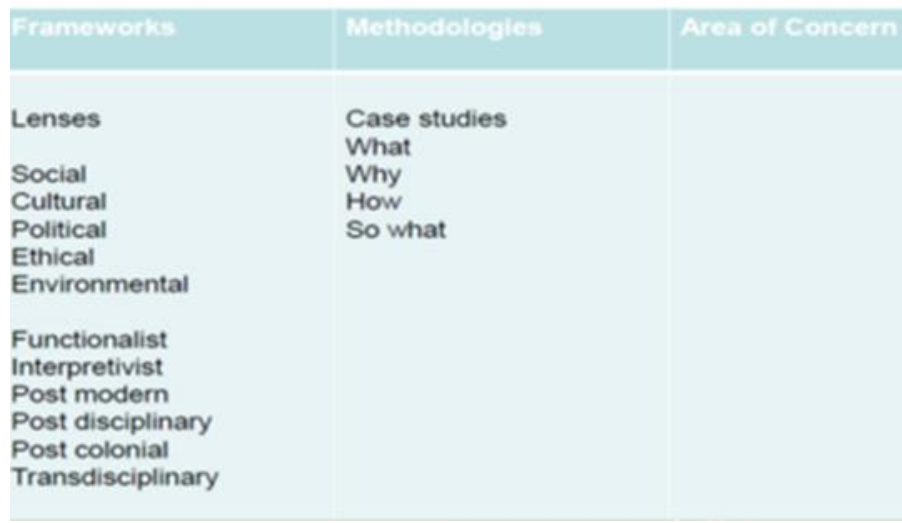

Figure 2: Methodology and Area of concern (FMA approach) to inspire thinking about designing a response to their own areas of concern

- Through dialogue we developed a shared area of concern and decided to develop a community of practice to write this joint paper on participatory approaches to adult education as well as some additional papers in this journal that have been developed as a result of the 'community of practice'.

The research conversation:

- Discussed many social, economic and environmental dimensions impacting on unemployment, development, capacity building and education.

- Demonstrated ways to work across a range of cultures, theories and disciplines to develop a response to challenges that span spatial, conceptual and temporal boundaries and the need to be informed by diverse ways of knowing. The approach to action learning and participatory action research combines theories in a complementary manner based on matching processes to address an area of concern - through asking questions about the implications of different choices for their research and for their practice (see Borradori, 2003, Gunaratne,2012).

The process strives to enable the participants to show personal and interpersonal agency in creating and co-creating new approaches that respond to the context and that take into account cultural diversity spanning the subjective, intersubjective and objective domains of their knowledge and the knowledge of the people with whom they undertake research.

The approach to PAR draws on Wenger et al $(1998,2009)$ on 'Learning, meaning and identity' and digital habitas as a basis for setting up communities of practice within and beyond organizational boundaries to create learning communities (adapted from Senge, 1994, 1999). Wadsworth's (2010) contribution to 'human inquiry for living systems' using participatory action research also provides inspiration. As does the work by Romm (2001) on the importance of 
combining appropriate methods to enhance representation and accountability; whilst my own transdisciplinary and cross cultural experiences as an action researcher in a range of urban and rural contexts and as an action learning facilitator in higher education provide a basis for the proposed project. In contrast to top down decision making or processes that favour control by specialists or professionals that often lead to unethical and unsustainable decisions, the research conversation participants were asked to think about alternative ways to engage with adult learners and young people.

They were asked to draw on a range of disciplines when considering an area of concern and invited to address contextual considerations (social, economic and environmental spanning different levels of praxis pertaining to education, development and capacity building to enhance employment opportunities) and to reflect on personal and interpersonal considerations from their own experience.

Contradictions between rhetoric and reality, paradoxes and the implications for policy and practice through dialogue were explored with regard to unemployment, education and training and the need to recognize prior learning and lived experience, in order to make a practical difference to the life chances of South Africans.

The process of reflection used the Design of Inquiring Systems Approach (meaning the questioning approach that explores many ways of knowing) to engage in participatory action research and action learning. The DIS approach enables a careful consideration of where to draw the boundaries of what and who is included and the consequences of leaving out particular people or issues when reaching a decision on who to allow to study specific courses at UNISA and under what conditions.

We discussed the importance of considering many ways of knowing. It was stressed that many entrepreneurs in rural and urban areas have skills that need to be recognized. Recognition of competencies in recycling, arts, for example could become the basis for an arts or business qualification linked with a sustainable living approach.

I suggested we consider the areas of concern for participatory action research and action learning spanning many different knowledge domains (drawn from West Churchman, 1979) as a possible starting point. These ways of knowing include the subjective (personal perceptions, values, emotions and intuition); objective (lived experiences and empirical knowledge) and intersubjective dimensions (understanding of the meaning of Ubuntu and its relevance for developing social capital) were highlighted originally by Habermas (e.g. 1984). Chuchman's five domains span: logic, empiricism, dialectic, idealism and pragmatism:

- Logic refers to the way in which arguments are structured and the relationship across ideas that build from premises to a logically supported conclusion. Argument needs to be developed so that the logical flow is continuous and so that it supports the conclusion. The flow of ideas upstream will affect the pool of experience and the conclusion downstream.

- Empiricism refers to both qualitative and quantitative dimensions of knowledge that reflect the meanings of diverse stakeholders by faithfully representing their points of view. 
Quantitative data are based on collecting data to represent patterns and weightings of the number of times particular ideas have been expressed, for example.

- The dialectic refers to the ability to engage in co-created knowledge that is intersubjective. The process used in this workshop modelled this approach to begin to 'unfold' the ideas of all the stakeholders and to sweep in the social, cultural, political, economic and environmental dimensions that affect the framing of an area of concern. We explored what needs to be included or excluded when considering unemployment in South Africa and education to address the needs of people of all ages. The potential of the young to learn from the old and vice versa through appreciation of lived experience, innovation, art, narrative and design needs to be further explored through participatory action learning and action research projects. Nussbaum and Glover (1995) have stressed the capabilities approach as a way to enable people to meet strategic needs through empowering them at home, at school, at work, at play and giving people a voice. State, market and civil society need to work together to enable and empower workers and learners through co-creating partnerships.

- Idealism is the domain of knowledge that refers to what ought to be done in ethical terms to meet ideals or essential living standards or quality of life, whilst expanding pragmatism ensures that the consequences of decisions for others and the environment are considered in the short, medium and long term through testing out ideas with people within and beyond the learning environment of universities and schools to create learning communities beyond the walls of the institutions.

This is an incomplete list however that needs to be extended to include:

- Non-anthropocentric knowing (De Waal, 2000, McIntyre-Mills, 2014) drawing on the environment as well as knowing through all our senses - including empathy and intuition along with:

- Respect for 'know how' developed through experience based on empirical trial and error

- Creativity in creating sustainable relationships with the land and

- Caring for future generations of life.

- 'Phronesis' or wisdom (Aristotle, see Irwin, 1985) to match the right knowledge in context so as to empower learners through providing them with appropriate pathways to learning within local contexts and with access to the wider environment (Fourade, 2006).

\section{Values and perceptions}

An open approach to education and respecting diverse ways of knowing is a starting point for people's education and community development. The struggle in South Africa for transformation was typified by student protests during Apartheid for the right to a free and equal education system. At UNISA we are reminded of the need to use education as a means to empower and this means beginning with the lived experiences of people (Han, Tandon, 2014) 


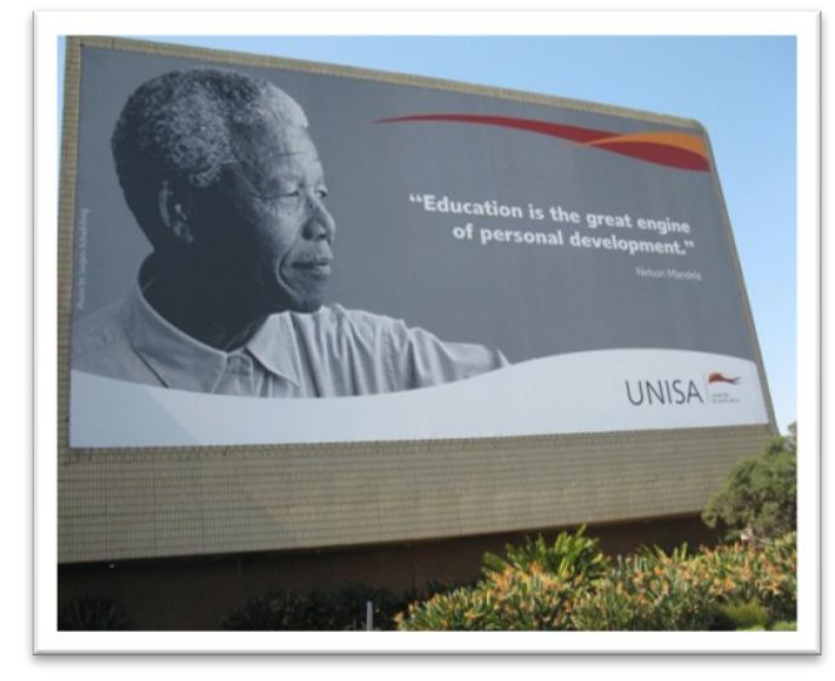

Figure 3: Education for empowerment begins with lived experience

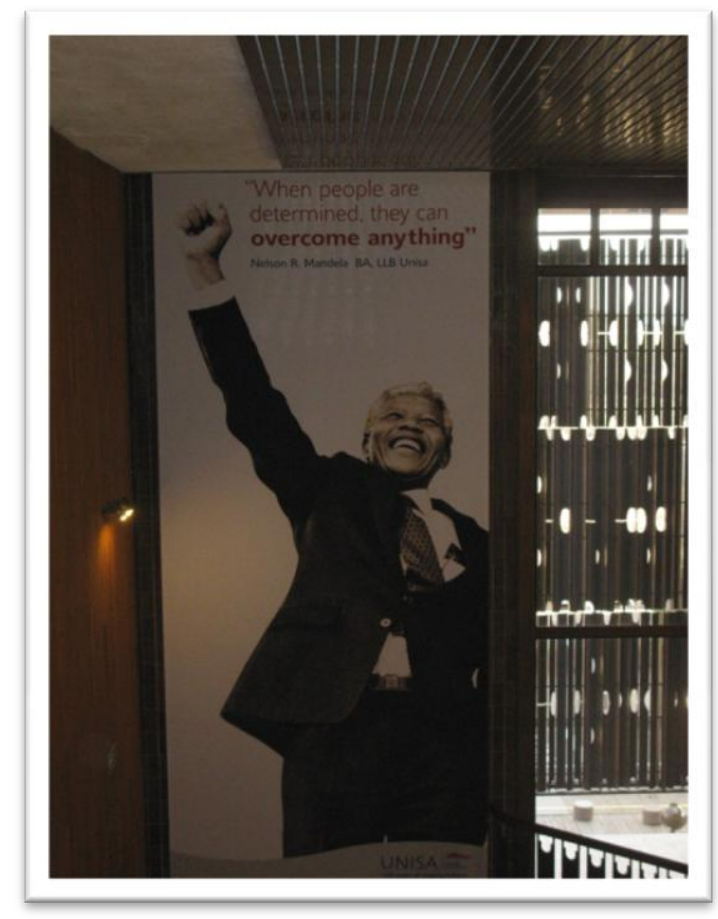

Figure 4: Mandela epitomises the mission of UNISA, namely to strive to overcome obstacles

Mangcu (2014) stresses that the challenge facing South Africa is to remember that freedom and democracy need to be worked at. He draws on Isiah Berlin's "Two Concepts of Liberty" and stresses that fighting for freedom successfully does not make one democratic. Keane (2009) cautions that for democracy to survive - let alone remain vibrant, it requires the active engagement of everyone in society. 
Desmond Tutu calls for us to live according to the principles of Ubuntu and he stresses this has implications for all aspects of our lives, including what we value and the way we relate to others. The call to address climate change by Desmond Tutu and the call to live in ways that reflect the philosophy of Ubuntu. He stresses that we are people through other people and we need to be keepers not consumers who live at the expense of others (including sentient beings) and future generations of life:

"it speaks of the very essence of being human. When we want to give high praise to someone we say, Yu, u nobuntu, hey so- and so- has Ubuntu,

Then you are generous, you are hospitable, and you are friendly and caring and compassionate. You share what you have. It is to say, my humanity is caught up, is inextricably bound up, in yours.... We belong in a bundle of life. We say a person is a person through other persons. It is not I think therefore I am. It says rather; I am human because I belong, I participate, and I share. A person with Ubuntu is open and available to others, affirming of others, does not feel threatened that others are able and good, for he or she has a proper self-assurance that comes from knowing that he or she belongs in a greater whole and is diminished when others are humiliated or diminished, when others are tortured or oppressed, or treated as if they were less than who they are...." Cited from Tutu ( 2013).

Wellbeing, and not only the economic bottom line, is important - social and environmental indicators of wellbeing need to support economic indicators need. Government response to human wellbeing is often based on economic development, which inadvertently increases consumerism, resulting in greater environmental degradation. Stewardship like all concepts is shaped by assumptions and values. Flannery (2012) considers that stewardship is based on awareness that the land and biologically diverse ecosystems are a cultural heritage on which the wellbeing of current and future generations depends. Anthropocentric versus non anthropocentric stewardship needs to be carefully considered to ensure that human consumption is not at the expense of environmental considerations and future generations of life (Parker, 2012).

Freedom cannot exist at the expense of democracy or vice versa. Currently the fight in carving up government contracts and the permission to spend public money on personal expenses has riddled government. South Africa is food insecure (see Crush and Fayne 2010) and imports more food than it exports. More than half of South Africans do not have regular access to enough food, according to the Human Sciences Research Council Report released in 2014, based on a survey conducted nationwide. Overall, $45.6 \%$ of the population are food insecure. The largest percentage of participants who experienced hunger (food insecurity) was in urban informal (32.4\%) and rural formal (37.0\%) localities (HSRC, 2014). Voices of opposition stress that political parties need to address not only unemployment but under employment and the daily stress of trying to make ends meet, living in debt or being destitute.

The future for South Africa lies in developing learning organisations and learning communities where people feel that they have a voice and a right to a voice and where they do not only participate in vertical democracy through elections that vote in elites who lose connections with the people they are supposed to represent. So the future lies in participatory democracy and more direct interventions:

"Participation is the cardinal principle of democracy - not only because of its intrinsic value, but also because it increases the political efficacy of citizens by giving them direct training in the 
policies and tools of governance. Almost 200 years ago, John Stuart Mill suggested that this kind of democratic training is best obtainable at the local level, where citizens can make decisions about issues they can immediately relate to, and then generalize that knowledge to the broader, national political system." (Mangcu, 2014: 31).

What is needed in South Africa is a greater emphasis on core principles and engagement with the people in discursive democracy, if not direct voting as suggested by Mangcu (op cit). Xolela Mangcu (2013) argues that Thuli Madonsela, the Public Prosecutor along with Bishop Desmond Tutu are some of the best examples of leaders left with integrity. The most powerless and voiceless are those who do not have the vote... they are young people, children, asylum seekers, the dis Abled, sentient beings who are commodified and traded and of course the planet which has no rights at all.

So the focus needs to be on the inadequacies of the nation state and the social contract. The recently published volumes "Systemic Ethics and Transformation from Wall Street to Wellbeing" (McIntyre-Mills, 2014) provide a plea and an example of a free downloadable architecture for doing things differently at the meso level.

Local level engagement and wide ranging goals appear to be suggesting new directions, but how do we join up the dots and become more mindful?

\section{Theoretical perspective and community of practice approach to consider the environment of the problem}

Systemic approaches consider cause, effect, feedback and the way in which relationships across variables are interrelated and perceived by the different stakeholders. This is because complex challenges cannot be considered in conceptual, spatial or temporal compartments. Stiglitz, Sen and Fitousi (2010) develop an argument for developing 'wellbeing stocks', rather than emphasising profit and productivity in a re-framed economy and society. This resonates with the Indigenous knowledge on the need to act as stewards for future generations. This mainstream publication 'Mismeasuring our lives' by the past Chief Economist of the World Bank, Stiglitz together with Amartya Sen the development economist provides a useful starting point for questioning and developing a more systemic response to building capacity to develop the social, economic and environmental dimensions of society to support a sustainable future. The work of Stuart Hall on critical heuristics and the need to question 'who gets what, when, why and with what implications', is also a vital dimension to praxis responses, as is his focus on the importance of listening to narratives about who we are and what we need to do to address unemployment within and beyond the boundaries of the nation state.

The Max-Neef Human Sustainability Index can be applied to valuing, measuring and managing environmental and human assets through considering our lives in terms of 'being, having, doing and interacting'. This index provides a possible architecture at each local government level to ensure that freedom of information, the right to a voice and a right to be heard is applied to the environmental wellbeing concerns of local residents. The engagement architecture that we could develop and test together enables diverse opinions to be mapped and scored in terms of social, 
economic and environmental indicators of what works why and how to support personal and environmental wellbeing. These perceptions could help policy makers narrow the gap between haves, wants and needs when addressing education and training service delivery to address perceived areas of concern( Brook Lyndhurst,, 2004, McIntyre-Mills et al 2014).

The research via a community of practice could break new ground on understanding social and cultural relationships and power dynamics within local government regions within learning organisations and learning communities as they relate to wellbeing and environmental stewardship.

\section{Public sector roles and functions have changed}

According to Bourgon (2004) the challenge for the public sector is to shift from responding to a predictable social, economic and environmental context to being innovative and responsive. This is equally relevant for the private and non-government sectors. Compliance in terms of the rules of law now needs to consider reframing and recasting the future of democratic governance to take into account our increased vulnerability and interconnectedness.

Policy and governance outputs and outcomes need to be responsive; one size does not fit all in increasingly diverse nation states. Currently the challenge is that on the one hand the nation state is too big to address the needs of diverse voters and too small to address the collective needs and common good of people in regional areas facing food energy and water challenges that will need a multilevel and multiagency approach to ensure social and environmental justice within and beyond the boundaries of the nation state.

The theoretical perspective developed by Nussbaum (2006) in 'Frontiers of social justice' is applied to address complex challenges within and across boundaries in order to address quality of life and capabilities for all. My own reflection spanned social, economic and environmental considerations. Climate change is a significant problem in Australia. There is little doubt that accelerated climate change will adversely affect wellbeing and sustainability in Australia (Flannery, 2005, Pretty, 2013, Stigltz et al, 2010) - particularly if we continue to consume at current rates (Davies \&World Institute, 2008 - resulting in significant devastation and a compromised quality of life. The impact of climate change has been underestimated (Lovelock, 2009, Rockström et al, 2009) and local solutions have been overlooked. Aboriginal cultures teach us about stewardship and relationships with the land, but these relationships have been lost in nonAboriginal cultures. As Major Sumner, an Ngarrindjeri Aboriginal elder from the periodically drought-ravaged lower Murray River in South Australia and custodian of the river stresses, we are the land and the land is us. Re-establishing relationships with the land is at the heart of effective cultural ecosystem management and can be fostered through cultural ceremonies (see http://www.mdba.gov.au/what-we-do/working-with-others/aboriginal-communities/ringbalin).

There is evidence that many desire more environmentally sustainable lives, but little is known about the influences on choices around the management of land, water, food and energy supplies that affect the environment. Government responses to human wellbeing are often based on economic development, which inadvertently increases consumerism, resulting in greater environmental degradation and a heavier carbon footprint. The implementation of coal plants and the lack of local government support for green energy sources are a case in point for both Australia 
and South Africa.

We know, therefore, that environmental sustainability and human wellbeing are intimately linked, but there is little knowledge about how this linkage can be built upon to improve both areas or how we can draw on the lived experience of people to create and co-create pathways to sustainable living through valuing different ways of living and sustainable knowledge that has stood the test of time. Attempts to address climate change are often based on policy information that is not grounded in people's experiences and fails to address what we do know about human behaviour or choices. How can we increase engagement in the environment that balances individual and collective wellbeing and simultaneously protects the environment when we know little about this nexus and when we do so little to provide opportunities for the recognition of prior learning and do not draw on cultural case studies of sustainable living?

Research needs to draw on diverse ways of knowing (Cruz et al, 2009) that could support regional governance (Wear, 2012) to support effective environmental management. There is evidence that many desire more environmentally sustainable lives, but little is known about the influences on choices around the management of land, water and food that affect the environment. Government response to human wellbeing is often based on economic development, which inadvertently increases consumerism, resulting in greater environmental degradation. We know, therefore, that environmental sustainability and human wellbeing are intimately linked, but there is little knowledge about how this linkage can be built upon to improve both areas through enhancing capacity building for sustainable living and sustainable employment.

Attempts to address climate change are often based on policy information that is not grounded in citizen experiences and fails to address what we do know about human behaviour or choices. The inherent link between engagement in civil society and community wellbeing (rather than profit) needs to be the focus of research.

The concepts of stewardship and resilience are important notions through which to explore the nexus across wellbeing, consumption choices and the environment. We need to develop a deeper understanding of how the intangible aspects of perceived wellbeing can be measured and how different kinds of knowledge can be applied to support social and environmental justice. But we also need to measure them in relation to the link between wellbeing and sustainability (Stiglitz et al (2010). Our conversation then explored the shared area of concern, namely that lived experience and alternative ways of knowing are not sufficiently appreciated.

The Ngarrindjeri care taker Major Sumner teaches that learning to appreciate water flows is based on years of experience of testing out ideas and drawing on the empiricism of learning from the land. But we need to also appreciate that non-anthropocentric care taking requires learning from narratives of what works, why and how. We need to 'join up the dots' and appreciate our interdependency on many forms of life.

Shiva (2011) for example stresses the need to learn from nature and from non-human animals. The wisdom of the earthworm to sustain organic material and the wisdom of the kangaroo, an environmentally evolved creature that suits the semi-arid environment and that fertilizes it with manure that sustains the bush on which it depends (Flannery, 2012). A post-colonial approach to 
agriculture could recognize appropriate farming in Australia and South Africa and draw on the experiences of the people in living sustainably..

The ability to live sustainably will require valuing different ways of knowing, learning and experiences, such as the ability to be an entrepreneur and to have the skills to create artworks and functional items out of recycled material. The ability to mend and recycle has been forgotten in a consumerist world.

Thus the issue of creating barriers to university entry, rather than pathways needs to be explored widely. Best practice examples of not merely recognizing prior learning through competency tests set by the university or other colleges for vocational education have already been implemented in Australia. For example in Alice Springs the Centre for Desert Knowledge and CAT demonstrate working in partnership with Indigenous Australians.

Thus the notion of participatory action research with those who have experience could be a methodology for learning to live sustainably.

The group then explored specific questions that flowed from their engagement with our shared area of concern, namely the need to respond to the education, development and employment needs of South Africans through enabling learners to achieve pathways to sustainable living. Many of the issues faced by South Africans are issues faced by those in other parts of Africa. The droughts in Tunisia, for example has led to protests and the flow of asylum seekers to Europe. Many also seek asylum in South Africa from other parts of Africa.

In Australia the social contract protects those within the boundaries of the state but not those who seek asylum from elsewhere. The issue of bounded governance and decision making that does not consider the consequences of social, economic and environmental choices for our neighbours has been raised by Joy Murray in the so-called Tuvalu test that demonstrates how our social economic choices affect our neighbours through rising sea levels. For example in Samoa, agriculture has been affected by rising sea levels and increased levels of salinity.

Thus the issue of employment and unemployment is one that needs to be placed within the context of the environment of the problem. Namely a sustainable future in which learning supports social, economic and environmental wellbeing.

After sharing my own concerns about the implications for climate change locally and regionally and showing the interconnectedness of social, economic and environmental considerations by means of a soft systems map which I reproduce below as follows, each participant was asked to raise their own areas of concern.

\section{Cosmopolitan area of concern}

The excessive consumption of energy resources impacts on the size of our carbon footprint (defined in terms of the Intergovernmental Panel on Climate Change (IPCC) IPCC formula, namely $\mathrm{E}$ (Emissions) = Population X Consumption per person X Energy Efficiency X Energy Emissions) The IPCC formula suggests that the privileged lives of some could lead to 'existential 
risk' for all forms of life on the planet (Bostrom, 2011). The 'price of inequality' - national and global has escalated. The global figure for displaced people passed 50 million for first time since the Second World War. The processing of asylum seekers offshore has become a human security risk for Australia, because compassion has been set aside in a bid to win votes by stressing border protection. The needs of the displaced are not addressed through the current architectures of democracy and governance.

My research question is: how should we live? How can we be more sustainable in our living choices? My research tests the hypothesis that decisions that are made at the lowest level possible are more likely to take into account the complexity of the decision maker (Flood and Carson, 2003)..

My area of concern is to address complex challenges. Complexity refers to the number and variety of variables that need to be considered and their relationships and the way in which they are valued by the different stakeholders. When doing research it is important to think in terms of both the big picture (context of the area of concern) and the small picture (perceptions of the different stakeholders). I am particularly concerned to think about what is included and excluded when I frame or conceptualize research. This involves more than merely reading the literature, thinking about different perspectives and the implications for the way in which the research is designed, it requires an approach that is grounded in awareness of many different ways of knowing drawing on many senses and based on a realization that learning from the environment is important. The way an issue is conceptualized shapes the design and whether qualitative and or quantitative data are collected. In order to enhance representation and accountability ( which are essential for ethics, democracy and governance) the testing out of ideas locally, regionally, nationally and in post national regions becomes increasingly important to address complex wicked challenges of poverty and climate change in a world where the gaps between rich and poor are becoming wider. Monitoring from below to ensure accountability and representation is increasingly important, given the panoptican tendencies of digital technology. This has implications for using digital media to foster communities of practice that support social and environmental justice by pooling resources ( see Wenger 1998).

To sum up my concern is the need for a different approach to the way in which we live our lives in terms of our consumption of energy resources, fresh water, transport and meat consumption and the implications for wellbeing and sustainable living (Pretty (2013).

Developing a greater number of connections enhances consciousness. Greenfield (2000, 2008) argues that the more we are able to think about our thinking the more conscious or mindful we become. This can help to create closer bonds and links as well as the capacity to bridge differences.

The research is located at the interface of capacity building, knowledge and biodiversity management, consciousness studies and systemic governance (McIntyre-Mills, 2006, 2010, 2014) and contributes to new ways to address the systemic social, economic and environmental challenges we face today. It brings together multiple areas looking for new solutions. The challenge is to learn to work with diversity and power (Flood and Romm, 1996) and to develop 
new forms of knowledge (Gibbons et al, 1994). Wellbeing is now widely located in mainstream trans disciplinary literature that re-frames what we value as a society, hence my research builds on the work of Joseph Stiglitz, Amartya Sen, Ann Florini, Danielle Archibugi , Yoland Wadsworth, Deborah Rose Bird, Mike Hulme, Carol Graham and Jenneth Parker of the Schumacher Institute, for example. The participatory action research explores whether the proposed architecture for engagement in participatory democracy and governance (Archibugi, 2010) could enable people to gain greater awareness of the implications of excessive consumption (Pretty, 2012, Urry, 2010) for stewardship (see Australian Gov. Caring for Country, 2013-2018). The specific challenge that this research addresses is to match forms of appropriate stewardship participation (Irwin and Stansbury, 2002, Jasonoff, 2003) that are accessible to diverse groups and not viewed with cynicism (Cooke, 2004). Significantly the research will assess whether participatory democracy and governance enhance sustainable living and wellbeing.

\section{The metaphor of weaving together strands of experience and creating a community of practice}

Indigenous Ngarrindjeri knowledge is based on understanding that river grasses enable the salinity to be drawn out of the soil to avoid toxicity during when the river levels are low. The metaphor of weaving together strands of experience through weaving artistic and functional objects such as mats, baskets and art works whist engaging in telling narratives about the dreaming and about current community rights and responsibilities enables people to think about self-others the environment including the next generation of life.

\section{Co-determination within Biospheres: Rethinking architectures of democracy and governance based on the pillars of morality: empathy and reciprocity}

The tendency to think in terms of specific disciplines rather than with respect for other ways of thinking has resulted in so-called 'enlightened', ethnocentric and anthropocentric thinking and practice that has led to policies that have affected the quality of agriculture and water management. My area of concern is to introduce a more responsive and open, transdisciplinary and cross cultural approach to policy making and policy implementation. Instead of making decisions in a top down manner we need to practice monitory democracy from below so that decisions match the needs of local people.

In Australia the gap between rich and poor has widened. The price of inequality is born by people and the environment. Most importantly the current social contract does not go far enough to protect the needs of non-citizens, namely young people, asylum seekers as well as the voiceless who are unable to express their needs.

The social contract extends rights and expects responsibilities to be fulfilled in return. But what about those who are voiceless, disabled, too young or without citizenship rights (displaced, asylum seekers or refugees)? (Carens, 1995, Nussbaum, 2006, Young, 2000).

In order to address this area of concern it is necessary to with a range of different theories spanning disciplines and to take inspiration from trans disciplinarity as well as cross cultural inspiration on cultural flows. Stanford research on non-anthropocentric approaches to fairness and unfairness shows that primates and other animals understand the concept of the fair distribution of resources 
and that a sense of morality and reciprocity guides the behavior of primates and other animals (including human animals). I also draw on Frans De Waal who stresses the need to recognise that we evolved not only through our ability to compete but through our ability to co-operate and to show empathy to others.

Frans De Waal (2009) stresses that morality, empathy and co-operation provided a basis for evolution, not only competition. Surely it is time to re-think the social contract which is far too narrowly defined to protect only human animals living within the boundaries of the nation state? Shiva argues that the greatest misuse of natural resources has been by nations and corporations and not by local communities that have acted as water democracies, for example in Bali, Indonesia and in Gujurat, India - water was sacred and carefully managed.

"Community rights are necessary for both ecology and democracy. Bureaucratic control by distant and external agencies and markets control by commercial interests and corporations [can] create disincentives for conservation..." (Shiva, 2002: 30-31).

I explained that the use of water could be used as a synecdoche for discussing participatory governance and democracy. In South Australia the flow of water has been affected by the introduction of dams and weirs. The upstream users benefit at the expense of down steam users, but this has been raised as a problem by Major Sumner, an Ngarrindjeri caretaker who has stressed that we need to think in terms of cultural flows. This means that our thinking and practice needs to be carefully considered so that we consider the consequences of our policy decisions for ourselves, others and the environment.

Critical systems thinking deals with complex wicked problems which comprise many diverse and interrelated variables which are perceived differently by different stakeholders with different values. Thus two examples of wicked problems are climate change, poverty that pertains to our rights and responsibilities to both citizens and non-citizens. The role of theory and its relationship to practice needs to be carefully considered in terms of policy and praxis.

Table 1: Debunking Containerist Approaches

\begin{tabular}{|c|c|c|c|}
\hline & Structure & Process & Action \\
\hline $\begin{array}{l}\text { Micro-level } \\
\text { Individuals }\end{array}$ & $\begin{array}{l}\text { Aarhus convention } \\
(1998)\end{array}$ & $\begin{array}{l}\text { Questions raised and posed to } \\
\text { local government by individuals }\end{array}$ & $\begin{array}{l}\text { Local government, NGOS } \\
\text { and individuals }\end{array}$ \\
\hline $\begin{array}{l}\text { Meso } \\
\text { States and regions }\end{array}$ & $\begin{array}{l}\text { Aarhus convention } \\
\text { Linked to Global } \\
\text { Covenant }\end{array}$ & $\begin{array}{l}\text { On line monitory democracy and } \\
\text { governance to address } \\
\text { state/market/civil society concern }\end{array}$ & $\begin{array}{l}\text { Networking NGOs and } \\
\text { INGOS to address } \\
\text { representation and } \\
\text { account } \\
\text { ability }\end{array}$ \\
\hline $\begin{array}{l}\text { Macro } \\
\text { Cosmopolitan } \\
\text { governance }\end{array}$ & $\begin{array}{l}\text { Legal structures to } \\
\text { support the Global } \\
\text { Covenant, Aarhus } \\
\text { convention } \\
\text { and Biospheres } \\
\text { Convention }\end{array}$ & $\begin{array}{l}\text { International law to support social } \\
\text { and environmental justice }\end{array}$ & $\begin{array}{l}\text { Global action to pass laws } \\
\text { in overlapping biospheres }\end{array}$ \\
\hline
\end{tabular}


Source: Adapted from Archibugi (in Wallace Brown and Held, 2010: 322 cited in McIntyre-Mills 2014, p129 as Architecture for cosmopolitan democracy in overlapping domains.

\section{Areas of concern raised by participants and specific research questions raised by members of the group in the next iteration of the conversation}

Akwasi Arko-Achemfuor raised the issue that unemployment is a major concern in South Africa and that training does not match the needs of those who need to achieve qualifications to earn a living. Recognition of prior learning needs to be given more attention. UNISA uses the rhetoric but does not apply it in practice. Alternative processes and pathways to learning opportunities need to be constructed that honour diverse kinds of knowledge and diverse ways of learning. Whilst competency based approaches to the assessment of prior learning were previously developed at UNISA that more could be done to apply this policy in practice through combining it with action learning processes and participatory action research approaches that develop communities of practice to address specific tasks through creating networks of reciprocity within and beyond the boundaries of the university to create learning communities (see Senge,1994) on learning organisations and learning communities ) with people in rural and urban contexts. The distance learning approach used at UNISA could help to foster support after the establishment of face to face communication on development opportunities. Partnerships could be explored with NGOs, the Public and Private sector to provide development opportunities that build on the social, cultural, economic and environmental know how.

Pinkie Mabunda stressed that her concerns dovetailed with those of Akwasi and that she believed there was a need to enable prior learning to be recognized and to re-establish some of the processes that had previously existed to ensure that pathways for learners are facilitated by matching responses to needs. Against the background of social transformation, experiential learning and practices of RPL have been evolving within the contemporary discourse of lifelong learning, in a context which includes flexible forms of educational provision, credit transfer frameworks, competence and work-based learning (WBL) (Pouget and Osborne 2004). Recognizing prior learning (RPL) is key to the agenda of widening participation of learners who have gained qualifications, expertise and/or entry to programmes using skills and experience gained informally and experientially from varying learning context (Scott 2010). Many researchers argue that through RPL domination of formal education as the learning context is challenged and new possibilities are presented for identifying, recognizing, assessing and valuing experiential learning, knowledge and skills (Gross 2005). In the context of South Africa, the development of RPL policies is also considered as a key contributor to the discourse of the social inclusion of historically marginalized groups (Michelson 1997; Harris 1999). Their research question is: how can prior learning be enhanced? What success stories can we draw on locally and what lessons can we learn locally and from elsewhere?

Kedibone Mokwena expressed concern about the need to provide opportunities for people living in urban and rural areas through engaging in participatory action research on entrepreneurial activity to make use of lived experience in surviving and making use of resources to create something out of nothing through bricolage or the creative use of found objects to be transformed into art works or functional objects. Her question is what works why and how? Participatory action research with rural and urban entrepreneurs could explore case studies of innovation and provide lessons for policy to support opportunities for entrepreneurs using recycled materials. 
Mokwena suggests developing a model of Vocational Education and Training (VET) for unemployed rural women in Winterveldt outside Pretoria. Unemployment is one of the major problems facing the contemporary world, especially in the so called third world. According to Blossfeld (1992) women are internationally regarded as the main driving force for household survival, economic growth and the alleviation of poverty in rural areas. Unfortunately in the developing world most women have no skills for employment. Barker (2003: 174) argues that an unemployed person is a person who is without work, is currently available for work particularly the developing world. About 130 million young people in developing countries (15-24 years) are classified as 'illiterate' with women representing 59 per cent (UNESCO 2008). Illiterate adults face serious employability issues, given their low level of knowledge and expertise. In India for an example, the major cause of unemployment is the slow pace of development. South Africa, a developing country is also experiencing these challenges, unemployment being conceivably the root cause of many other problems, such as high crime rates, violence, and abject poverty. Blacks were severely repressed under apartheid and may not have developed the entrepreneurial and social skills necessary to enter and be successful in self-employment ventures. As a result the South African government has put in place policies and programmes aimed at reducing the rate of unemployment in the country. The relevance of VET for this study may be traced back to the introduction of the Skills Development Act (SDA) No 97 of 1998, the passing and implementation of the Adult Basic Education and Training (ABET) policy 52 of 2000 in South Africa which advocate for recognition of formal, informal and non-formal education in an integrated education and training approach as well as the White Paper for Post-School Education and Training (2013) which embraces the concept of lifelong learning affirming that learning occurs throughout a person's life in many forms(see Butler with Taylor, 2009. These Acts together with other legislation on VET are some of the policies which were implemented by the South African government with the goal of enhancing employment opportunities for adults particularly women who in this study are the chief economic providers responsible for maintaining the household.

This research will be conducted in the Winterveldt area situated forty kilometres North West of Pretoria. It is made up of several villages where people live in mostly informal housing comprising corrugated tin huts. Adults and in particular women are without any form of employment because of lack of skills (see Davids et al, 2005:25). Without basic education and training, rural Black illiterate women could remain cut off from the social, economic and political activities of the country (Quan Baffour (2012: 91).

The main research question for this study will be: What could a model of vocational education and training for unemployed rural women look like and how could it be developed? The concept Vocational Education and Training is used interchangeably by different scholars. This study is underpinned by the transformational paradigm which argues that social reality is historically bound and is constantly changing depending on social, cultural and power-based factors (Freire, 2007). As a study located in Freirean theory of dialogue it will employ a qualitative research design using action research where participants will talk about themselves and situations. The study seeks to develop an appropriate model of vocational education and training for unemployed rural women. In order to achieve the stated aim, the study sets out to:

- Establish unemployed women's specific needs for vocational education and training. 
- Identify a) current vocational education and training practices and to come up with a model appropriate to unemployed rural women. b) Strategies that can be adopted in developing a model of vocational education and training for unemployed rural women. c) Factors and intervention mechanisms that can be used to achieve positive results in the development of a model of vocational education and training.

- Determine how a model of vocational education and training can contribute to the enhancement of employment opportunities for rural women.

Esther Njiro expressed her interest in fostering more opportunities to facilitate learning through using distance learning digital technology more inclusively and creatively to enhance pathways for learning. Her interest is in responding to the diverse needs of distance learners who may have limited connectivity.

Her points raised the concern that technology is a means to an end that may be used to include or exclude, depending on the level of digital know how. Many different ways of knowing need to be appreciated in order to empower learners to develop their capacity and to progress on a pathway to social, economic and environmental wellbeing.

Participatory or collaborative learning using computer supported technology involves everyone in identifying their learning needs and opportunities and in the actions required to address them challenging the conventional biased preconceptions about people's knowledge and methods of acquiring knowledge (Albert and Campbell, 2008). The participation metaphor is characteristic of how, using social software tools, learners engage in the processes of social interaction, dialogue and sharing, all of which are linked to socio-cultural theory (Lave \& Wenger, 1991; Vygotsky, 1978). However, learners are also capable of creating and generating ideas, concepts and knowledge, and the ultimate goal of learning in the knowledge age is to enable this form of creativity. Current views of learning regard the notion of a teacher-dominated classroom and curriculum as obsolete, and embrace learning environments and approaches where students take control of their own learning, make connections with peers, and produce new insights and ideas through inquiry (McLoughlin and Lee, (2007). Thus, to keep pace with the content creation processes enabled by Web 2.0 and social software, it appears to be necessary to go beyond the acquisition and participation dichotomy. Paavola and Hakkarainen (2005) propose the knowledge creation metaphor of learning, which builds on common elements of Bereiter's (2002) theory of knowledge building, Engeström's (1987; 1999) theory of expansive learning, and Nonaka and Takeuchi's (1995) model of knowledge creation. Mishra and Jain (2002) demonstrate instructional approaches for behaviourism, cognitivism and constructivism learning theories. These participatory approaches include visualization, games, interviewing, group work, and segmenting course content for flexibility in learning (see International Institute for Environment and Development, 2005). To sum up, learner centred education needs to be about self-reflection, be flexible, responsive, connected and relevant to current challenges (Clegg and Heap, 2006, Gadamar, 2001, McLoughlin and Lee, 2007, Strijbos et al., 2004, Weller, 2000).

Norma Romm stressed that her area of concern is on teaching and research methodology and ways in which learning is facilitated. Norma played the role of observer and documented the process and content of the workshop. 


\section{Developing an alternative vision for education and employment}

Through striving to reveal 'in the small new ways of seeing the whole' (Adelman, 2013, 9) we could co-create new ways of engaging adults and young people in learning for a sustainable South Africa. This could provide lessons for cosmopolitan approaches to re-discovering ways to live through recycling and using resources creatively. It could also foster a sense of stewardship rights and responsibilities (Flannery, 2012) that are translated into new approaches to economics and business. Where success is valued not in terms of growth and profit, but in terms of distribution and living sustainably by valuing quality of life supported by:

- Socially inclusive communities in which people feel safe, appreciated, respected and happy and in which they are accountable for the governance of sustainable resources (see Florini, 2003, Graham,2011)

- Economically sustainable communities where people work and live in ways that create and re-create an environment that will continue to support the current and future generations through caring for food, energy and water supplies.

- This community of practice research initiative is significant in so far as it contributes to developing insight and foresight into many different ways of knowing and the importance of appreciating diversity in the tertiary education and training sector. It needs to strive to foster and provide pathways for diverse forms of knowledge including 'verbal, visual, physical, musical, mathematical, introspective and interpersonal' (Bounfour and Edvinssen, 2005, Gardner, 2008) and thus develop human capacity to address complex socio-environmental challenges (Ehrlich and Ehrlich, 2013).

- Democracy and governance are in need of improvement (Hulme, 2009, Giddens, 2009) and lessons learned about sustainable living could help to revitalize our approaches to ethics, representation and accountability.

- It seems to me that diverse ways of knowing hold the key to human and environmental security.

- The argument developed in "Systemic Ethics" is that the containerist approach to science, democracy, ethics and governance is a core part of the problem. This book stresses that the social contract is far too narrow to protect the more than 50 million displaced people who are non-citizens and thus considered to be outside the frame of reference of state protection. The enclosure acts based on Hardin's paper and Locke's argument based on the notion of the Tragedy of the Commons is part of the problem. As detailed below there is no research to support this argument.

- Current challenges today such as social, economic and environmental issues associated with growing numbers of displaced people, poverty, conflict, food insecurity as a result of shrinking agricultural land, water shortages, growing urbanization, energy shortages associated with using non-renewables, nuclear disasters on the scale of Fukushima are examples raised by the United Nations and Vandana Shiva and Maude Barlow. The issues need a new approach to the architectures of governance on a planetary scale. This book explores ways of doing things differently.

- The best practice examples can be found in many contexts from the survival strategies in informal housing areas to the declaration of rights to nature in Bolivia, Peru and Ecuador. 
The lived experience of Ubuntu in Africa and a sense of connection with nature in South American nations provide some telling directions for the future.

\section{Conclusion: our goal is to work across boundaries through co-creating a community of practice to address a shared concern}

Finding ways to link with local government and local NGOs to foster employment opportunities is important. We proposed an approach to working across boundaries as being as relevant to education as it is to community development. The process could help to enhance representation and accountability through exploring ideas and engaging in dialogue by testing the implications of decisions with others so as to balance individual needs and collective needs for a more sustainable way of life.

\section{References}

Aarhus Convention (1998). 'On access to information. Public participation and access to justice in environmental matters',

Denmark,25June.http://aarhusclearinghouse.unece.org/resources.cfm?c=1000069

Akomfrah, J. (2013). 'The Stuart Hall Project. Documentary', produced by David Lawson \& Lina Gopaul and directed by John Akomfrah.

Albert, S \& Campbell (2008). 'The Challenge of Participatory Technologies for Teaching and Learning at Ontario Universities'. In Jennie Piekos, Research Associate Council of Ontario Universities. Retrieved from www.cou.on.ca/.../the-challenge-of-participatorytechnologies-for-t

Archibugi, D. (2008). 'The architecture of cosmopolitan democracy' in The Global Commonwealth of Citizens: Towards Cosmopolitan Democracy. Princeton University Press.

Australian Public Service Commission (2007). 'Tackling Wicked Problems: A Public Policy Perspective'. Australian Public Service, Canberra.

Barker, R. L. (2003). 'The social work dictionary', $5^{\text {th }}$ Ed. Washington, DC: National Association of Social Workers Press

Bateson, G., (1972). 'Steps to an Ecology of Mind', Ballantine, New York.

Bausch, K. 2006, 'Be your enemy: The Contributions of West Churchman to Doing Better Governance and International Relations' In McIntyre-Mills, J. Rescuing the Enlightenment from Itself: Critical and Systemic Implications for Democracy, C. West Churchman Series, Vol. 1, Springer, New York, Boston, London.

Beck, U. (2010). 'Climate for change, or how to create a green modernity'. Theory, Culture and Society. 27(2-3):254-266

Beck, U. and Sznaider, N. (2006). 'Unpacking cosmopolitanism for the social sciences: a research agenda' The British Journal of Sociology 57.1-23.

Beer, S. (1974). 'Designing Freedom', Wiley, London.

Bereiter, C. (2002). 'Education and mind in the knowledge age'. Hillsdale, NJ: Erlbaum.

Berlin, I. (1958). 'Two Concepts of Liberty.' In Isaiah Berlin (1969) Four Essays on Liberty. Oxford University Press, Oxford.

Bird, J. and Clarke, S. (2000). 'Racism, hatred and discrimination'. J. of Psycho-Analysis of Culture and Society. 4 (2): 332-335. 
Blossfeld, H (1992). 'Is the German dual system a model for a modern vocational training system? A cross-national comparison of how different systems of vocational training deal with the changing occupational structure', International Journal of Comparative Sociology 23: 168 $-81$.

Boettcher, J. V. (2007). 'Ten Core Principles for Designing Effective Learning Environments: Insights from Brain Research and Pedagogical Theory'. Innovate: Journal of Online Education. Retrieved from www.innovateonline.info/index.php?view=article\&id=54

Bonanno, G. (2004). 'Loss Trauma, and Human Resilience'. American Psychologist 59: (1) 20-28.

Borradori, G. (2003). 'Philosophy in a time of terror. Dialogues with Habermas and Derrida'. Uni of Chicago Press.

Bostrom, N. (2011). 'Existential risk prevention as the most important task for humanity' Faculty of Philosophy \& Oxford Martin School University of Oxford www.existential-risk.org

Boulding, K. (1956). 'General Systems Theory - the skeleton of Science' Management Science. 2, 197-208.

Bourdieu, P. (1999). 'The weight of the world. Social suffering in contemporary society'. Cambridge. Polity.

Brook Lyndhurst, (2004). 'Liveability and sustainable development'. Final Report for ODPM, London.

Brundtland, G. 1987, http://www.worldinbalance.net/agreements/1987-brundtland.html The report "Our Common Future".

Burns, D. (2007). 'Systemic Action Research. A Strategy for whole system change'. Bristol. Policy Press.

Butler, J. with Taylor, S. (2009). 'Interdependence’. In Taylor, A 2009. Examined Life: excursions with contemporary thinkers. The New Press. New York.

Capra, F. (1996). 'The web of life: A new synthesis of mind and matter', Harper Collins.

Carens, J. (1995). 'Aliens and Citizens: the case for open borders', In The rights of Minority cultures, Ed Kymlicka, W. Oxford. Oxford University Press.

Carspecken, P.F. (2014). 'Critical Ethnography in Educational Research'. Routledge. New York

Christakis, A. (2006). 'A retrospective Structural Inquiry into the predicament of Humankind: Prospectus of the Club of Rome'. In McIntyre-Mills, J. Ed. Rescuing the Enlightenment from Itself. Critical and Systemic Implications of Democracy, Volume 1 of the ' $\mathrm{C}$. West Churchman and Related Works Series', Van Gigch, J (series editor), Springer, London.

Christakis, A. and Flanagan, T. (2010). 'The talking point: A collaboration project of 21st Century Agoras'. Information Age Publishing.

Churchman, C. West, (1982). 'Thought and Wisdom', Californian. Intersystems Publications.

Churchman, C. West., (1971). 'The Design of Inquiring Systems'. New York. Basic Books.

Churchman, C. West., (1979). 'The Systems Approach and its Enemies'. New York. Basic Books.

Clegg, Phil and Heap, J. (2006). 'Facing the Challenge of E-Learning: Reflections on Teaching Evidence-Based Practice through Online Discussion Groups'. Innovate: Journal of Online Education. September 2006. www.innovateonline.info/index.php?view=article\&id=290

Cobbett, E. and Germain, R, (2012). 'Occupy Wall Street' and IPE: Insights and Implications Journal of Critical Globalisation Studies, Issue 5: 110-113.

Collins. R. (2010). 'Geopolitical conditions of internationalism, human rights and world law'. Journal of Globalisation Studies. (1): 29-45. 
Comaroff, J. (2011). 'Theory from the South: or how Europe is evolving towards Africa'. Key note address at Knowledge and value in a Globalising world. Disentangling dichotomies, querying unities. University of Western Australia. Perth 5-5th July.

Cooke, B. (2004). 'Rules of thumb for participatory change agents Participation: From Tyranny to transformation?' New York. Zed Books.

Crossen, T. and Niessen, V. (2007), NGO standing in the European Court of Justice - Does the Aarhus Regulation Open the Door? RECEIL 16 (3) 332-338. ISSN 09628797 at 332.

Crush, J. and Fayne, B. (2010). 'Pathways to Insecurity: Urban Food Supply and Access in Southern African Cities', Urban Food Supply and Access in Southern African Cities African Food Security Urban Network, 2010.

Cruz, I. Stahel, A. Max-Neef, M. (2009). 'Towards a systemic development approach' Ecological Economics, 68, 2021-2030

Davies, JB., and World Institute (2008). 'Personal wealth'. Oxford University Press.

De Waal, F. 2009, 'The Age of Empathy nature's lessons for a kinder society'. Harmony.

Ehrlich, P and Ehrlich, A. (2013). 'Can a collapse of global civilization be avoided?' Proc of the Royal Society of Biological Sci. Sep 22, 2013; 280(1767): 20131193.

Elliot, A. and Urry. J. (2010). 'Mobile Lives'. Routledge, New York.

Faist, T. (2009). 'The transnational social question'. International Sociology. 24: 17-36.

Fischer \& Konomi, 2005 Fischer, G. \& Konomi, S. (2005). ,Innovative media in support of distributed intelligence and lifelong learning'. In Proceedings of the Third IEEE International Workshop on Wireless and Mobile Technologies in Education (3-10). Los Alamitos, CA: IEEE Computer Society.

Flanagan, T. and Bausch, K. (2011). 'A democratic approach to sustainable futures. A workbook for addressing the global problematique’. Ongoing Emergence Press. Riverdale.

Flannery, T, (2012). 'After the Future: Australia's New Extinction Crisis'. Quarterly Essay Issue 48.

Flannery, T. (2005). 'The weather makers. The history and future impact of climate change'. Text Publishing, Melbourne.

Flannery, T. (2010). 'Here on earth. An argument for hope'. Text Publishing. Melbourne

Flood, R. \& Carson, E. (1993). 'Dealing with Complexity: An Introduction to the Theory and application of Systems Science', 2nd. ed., Plenum, London.

Flood, R. \& Romm, N. (1996). 'Diversity management: triple loop learning', Wiley, Chichester.

Florini, A., (2003). 'The Coming Democracy'. Island Press, Washington DC.

Folke, C. (2006). 'Resilience: The emergence of a perspective for social-ecological systems analyses'. Global Environmental Change 16 253-267.

Follesdal, A. (2006). 'Subsidiarity, democracy and human rights in Europe'. J of Social Philosophy.37 (1):61-80.

Foucault, M. and Gordon, C.(1980).Eds, 'Power/Knowledge'. Harvester.Brighton.

Fourade, M. And Savelsburg, J. (2006). 'Global Processes, National Institutions, Local Bricolage: shaping law in an era of globalisation'. Law and Social Inquiry. 31(3):515-519.

Freire, P. (1970). 'Adult Literacy Process as Cultural Action for Freedom'. 1970. Harvard Educational Review. 40(2), Summer 1970

http://hepg.metapress.com/content/121179/?p=a88f9f08136c4c20b50fbc74adcd18c7\&pi=0

Freire, P. (1982). "Creating alternative research methods. Learning to do it by doing it", in Hall, B., Gillette, A. and R. Tandon (eds.) Creating Knowledge: A Monopoly. Society for Participatory Research in Asia, New Delhi, pp. 29-37. 
Freire, P. (2007). 'Pedagogy of the oppressed'. New York: Continuum.

Friere, P. (1985). 'The politics of education', Begin and Garvey, Inc. Westport, CT 06881

Gardner, H. (2008). 'Multiple intelligences: new horizons in theory and practice'. New York Basic Books

Gadamar, H.G. (2001). 'Education is self-education' Journal of Philosophy of Education. Vol. 35 No 4.

Gallhofer, S. \& Chew, A. (2000). 'Introduction: accounting and indigenous peoples', Accounting, Auditing and Accountability Journal, 13(3):256-267.

Galtung, J. (1990). 'Cultural Violence', Journal of Peace Research, Vol. 27. No 3. 291-305. Sage.

Gamble, A. (2000). 'Economic Governance' In Pierre, J. Ed. 'Debating governance: authority, steering and democracy'. 1st edition Oxford University Press, Oxford.

Gandhi, L. (1966). Affective communities: anti-colonial thought, fin-de-siècle radicalism and the politics of friendship, Duke University Press.

Gaventa, J. (2001). 'Global Citizen Action: Lessons and Challenges' In Edwards, M. and Gaventa, J. eds. Global Citizen Action. Lynne Rienner.Boulder.

Getano Lui, (1993). 'Voices from the Land'. Boyer lecture Series.

Gibbons, M. Limoges, C., Nowotny, H., Schwartzman, S., Scott, P. \& Trow, M. (1994). 'The New Production of Knowledge: The dynamics of Science and Research in Contemporary Societies', London. Sage.

Giddens, A. (2009). 'The politics of climate change'. Polity. Cambridge

Goldsmith, J. and Posner, E. (2005). 'The limits of International Law'. Oxford: Oxford University Press.

Gould, C. (2007). 'Transnational Solidarities' Journal of Social Philosophy, 38(1), 148-164.

Gouldner, A.W. (1971). 'The Coming Crisis of Western Sociology'. London. Heinemann.

Graham, C. (2011). 'The pursuit of happiness: an economy of well-being'. Brookings Institution Press. Washington.

Greenberg, G. \& Tobach. (1987), 'Cognition, language and consciousness: integrative levels', Vol. 2. Hillsdale New Jersey.

Greenfield, S. (2000). The private life of the brain: emotions, consciousness and the secret of the self. Wiley. New York

Greenfield, (2003). Tomorrow's People How 21st Century Technology is changing the way we think and feel. Penguin

Greenfield, S. (2008). ID: The quest for meaning in the 21st century. Sceptre, Hodder and Stoughton, London.

Gunaratne, S.A. (2009). 'Globalization: a Non Western perspective: the bias of social science/communication oligopoly'. Communication, Culture and Critique (2) 60-82.

Habermas, J. Derrida, J and Borradori, G. (2003). 'Philosophy in a time of terror Dialogues with Jurgen Habermas and Jacques Derrida'. University of Chicago Press.

Habermas, J., (1984). 'The theory of communicative action'. Beacon: Boston.

Hall, B and Tandon, R (2014). 'No more enclosures: knowledge democracy and social transformation' Open Democracy https://www.opendemocracy.net/author/rajesh-tandon, Open Democracy 20 August 2014

Hardin, G. (1968). 'The Tragedy of the Commons', Science, 162:1243-1248.

Harris, L.D. and Wasilewski, J. 2004, 'Indigenous Wisdom of the People's Forum', Systems Research and Behavioural Science, Vol. 21:505-514. 
Harrison, K. (2002). 'Policy perspectives: Social Capital'. In Parnell, S. Swilling, M and Wooldridge, D. Democratising local government. The South African experiment. University of Cape Town Press. Landsdowne.

Hayden, P. (2010). 'The environment, global justice and world environmental citizenship'. In Brown, G.W. and Held, D. Cosmopolitanism, Polity Cambridge

Held, D. et al. (2005). 'Debating Globalization'. Polity Cambridge.

Held, D.(2004). 'Global covenant: The social democratic alternative to the Washington Consensus'. Polity.

Heller, P. (2001). 'Moving the state: the politics of democratic decentralisation in Kerela, South Africa, and Porto Alegra'. Politics and Society, Vol. 29 No 1 131-163

Heycox, J., Meadows, P. and Vernon, B. (1997). 'Measuring environmental expenditures and revenues in Local Government', Environment and Energy Statistics Section Australian Bureau of Statistics, Australian Centre for Regional \& Local Government Studies Working Paper No 2. University of Canberra

Hickey, S. and Mohan, G. (Eds) (2004). 'Participation: From tyranny to transformation?' Zed Books. New York.

Hil, R.(2013). 'Beyond the cyber cell' In Advocate, Vol. 20, No 3. Pp28-29

Hill Collins, P. (2000). Black Feminist Thought: Knowledge, Consciousness and the politics of Empowerment. Routledge. New York.

Hulme, M. (2010). 'Cosmopolitan Climates. Hybridity, Foresight and meaning'. Theory, Culture and Society. Vol. 27 (2-3): 267-276.

Hulme, M. (2011). 'Climate Change and four narratives of growth'. AHTC Workshop. University of Cambridge. http://climatehistories.innerasiaresearch.org/wpcontent/uploads/2011/01/Mike-Hulme.pdf. Accessed 8 Feb 2011.

Human Sciences Research Council, (2013). 'South African national health and nutrition examination survey’ ( SANHANES-1) Published by HSRC Press, Private Bag X9182, Cape Town, 8000, South Africa,www.hsrcpress.ac.za,First published: Launch edition 2013,Second edition published 2014

International Commission on the Future of Food and Agriculture (2007). 'Manifesto on the future of seeds' www.future-food.org

International Institute for Environment and Development (2005).Participatory Learning and Action. Retrieved December 4, 2007 from www.iied.org/NR/agbioliv/pla_notes/about.html\#b

Irvin, R.Stansbury, J.(2002). Citizen participation in decision making. Public Administrative Review.64:1:55-65.

Jasonoff, S. (2003). 'Technologies of humility: citizen participation' in governing science. Minerva. 41:223-44.

Jessop, S. (2009). 'Children's participation: an Arendtian criticism'. Educational Philosophy and Theory. Vol. 43. No 9 Article first published online: 8 NOV 2009 DOI: 10.1111/j.14695812.2009.00560.x.

Keane, J. (2009). The life and death of democracy. Simon and Schuster. London.

Kirby, M. (2013). What would Ghandi do? Penguin: New York

Knowles, M. (1978). The Adult Learner: A Neglected Species 2nd ed. Houston. Gulf Publishing Company.

Lave, J. \& Wenger, E. (1991). 'Situated learning: legitimate peripheral participation'. Cambridge, England: Cambridge University Press 
Levin, S. (2006). 'Learning to live in a global commons: socioeconomic challenges for a sustainable environment'. Ecological Research 21:328-333.

Lovelock, J. (2009). The Vanishing Face of Gaia. Allen Lane.

Maloney, W. Jordan, G. and McLaughlin, A. (1994). 'Interest Groups and Public Policy' J of Public Policy, 14: 17-38

Mangcu, X (2014). 'The arrogance of power: South Africa's leadership meltdown'. Tafelburg. Cape Town

Marr, B. 2005.Perspectives on Intellectual Capital. Multidisciplinary insights into management, measurement and reporting. Elsevier,

Max-Neef, M. 1991.Human Scale Development. Apex. London.

McIntyre-Mills, J. (2006b). 'Systemic Governance and Accountability: working and re-working the conceptual and spatial boundaries of international relations and governance'. Volume 3 of the 'C. West Churchman and Related Works Series', Springer, London.

McIntyre-Mills, J (2010). 'Wellbeing, mindfulness and the global commons'. Journal of Consciousness Studies. 17, (7-8) 44-72.

McIntyre-Mills, J (2014). 'Systemic ethics and non-anthropocentric stewardship: Implications for transdisciplinarity and cosmopolitan politics Springer, New York.

McIntyre-Mills, J with Devries, D and Binchai, N. (2014). 'Wall Street to Wellbeing: Joining up the dots through participatory democracy and governance to mitigate the causes and adapt to the effects of climate change:' Springer, New York.

McKay, V. and Romm, N. (1992). People's Education in Theoretical Perspective. Mascew Miller. Cape Town.

McLoughlin, C. \& Lee, M.J.W. (2007). Social software and participatory learning: Pedagogical choices with technology affordances in the Web 2.0 era. In Proceedings ascilite, Singapore pp 664-675. Retrieved from http://www.ascilite.org.au/conferences/singapore07/procs/mcloughlin.pdf

Midgley, G. (2000). Systemic Intervention: Philosophy, Methodology, and Practice. Kluwer. New York.

Mishra \& Jain (2002) . Designing an Online Learning Environment for Participatory Management of Displacement, Resettlement and Rehabilitation. Retrieved from www.col.org/pcf2/papers/mishra.pdf

Murray, J. Dey, C. and Lenzen, M. (2007). 'Systems for Social Sustainability: Global Connectedness and the Tuvalu Test'. Cybernetics and Human Knowing. 14 (1): 87-105.

Nazarea, V. (2006). 'Local knowledge and memory in biodiversity conservation', Annual Review of Anthropology. 36.pp 317-335.

Nonaka, I. \& Takeuchi, H. (1995). The knowledge-creating company: how Japanese companies create the dynamics of innovation. New York: Oxford University Press.

Nussbaum, M. \& Glover, J. (1995). Women, Culture and Development: A study of Human Capabilities. Oxford. Clarendon Press

Nussbaum, M., (2006). 'Frontiers of justice', London. Harvard University

Oliver, R. (1999) Exploring strategies for online teaching and learning, Distance Education, 20 (2): $240-254$

Paavola, S. \&Hakkarainen, K. (2005).'The knowledge creation metaphor - An emergent epistemological approach to learning'. Science and Education, 14(6), 535-557. 
Parker, J. (2012). 'Transdisciplinary systems approach to paradigm change in sustainable economy' In The Systemist, 34 (3) Winter 2012, 138-149

Pretty, J. (2013). 'The consumption of a Finite Planet: Well-being, Convergence, Divergence and the Nascent Green Economy'. Environmental and Resource Economics. DOI 10.1007/s10640-013-9680-9

Quan-Baffour, K P (2012). 'The Liberative Power of Education: Adult Basic Education as Empowerment Tool for Rural Women' In Studies of Tribes and Tribals 10(2) 91-97.

Republic of South Africa. Department of Higher Education and Training. (2014). White paper on Post-Schooling Education and Training. Pretoria

Republic of South Africa. Department of Education. ( 2000). Policy 52 of 2000 on Adult Basic Education and Training. Pretoria

Republic of South Africa. (1998). Skills Development Act 97 of 1998. Pretoria

Ritchey, T. (2011). Wicked Problems - Social Messes Risk, Governance and Society, 17, 2011, 16

Rittel, H. and Webber, M. (1984). Planning problems are wicked problems Developments in Design Methodology. New York: Wiley.

Rockström, J., Steffen, W., Noone, K. (2009). 'A safe operating space for humanity' Nature 461: $472-475$

Rogers, J. (2007). Adults Learning 4th ed., United Kingdom: Open University Press.

Romm, N. (2001). 'Accountability in Social Research: issues and debates'. Kluwer. London.

Romm, N. (2002). 'A trusting constructivist view of Systems Thinking in a Knowledge Age'. In Systems Theory and Practice in a Knowledge Age. In Ragsdell et al .New York. Plenum.

Romm, N. (2010). The New Racism. Springer. London.

Rose, D.B.(2004). Reports form a wild country. University of New South Wales Press. Sydney.

Rose, D.B. (2005). 'Dislocating the Frontier' http://epress.anu.edu.au/dtf/html/frames.php see http://epress.anu.edu.au

Schumacher, F.F. (1973). Small is beautiful. Economics as if people mattered. Harper and Row. New York.

Senge, $\mathrm{P}$ et al (1994). 'The fifth discipline fieldbook: strategies and tools for building a learning organisation'

Senge, P. ,Kleiner, A. Roberts, C, Ross, R., Roth, G. and Smith, B (1999). 'The dance of change: the challenges of maintaining momentum in learning organisations', New York Double Day.

Shiva, V (2002). 'Water wars: privatization, pollution and profit', London, Pluto Press.

Shiva, V. (2011). 'Earth Democracy', Portland University, http://www.youtube.com/watch?v=UOfM7QD7-kk/

Singer, P., (2002). 'One World: The Ethics of Globalisation', Text Publishers, Melbourne.

Stern, N, (2007). 'The Economics of Climate Change'. Cambridge. Cambridge University Press

Stiglitz, J. Sen, A. And Fitoussi, J.P. (2010). 'Mis-measuring our lives: why the GDP doesn't add up'. The New Press. New York,

Stiglitz, Joseph E. (2012). The Price of Inequality: How Today's Divided Society Endangers Our Future. WW Norton.

Tutu, D (2013). www,thinkexist.com/quotes/bishop_desmond_tutu/ 5 June 2014

Treaty of Maastricht (1992). Article 5 on Subsidiarity.

Ulrich, W. (1983). Critical heuristics of social planning: a new approach to practical philosophy. Wiley. New York. 
UNESCO, (2007). 'Biosphere Reserves: Dialogue in biosphere reserves'. References, Practices and Experiences. ISSN 2071-1468. Paris. UNESCO

United Nations Climate Change Summit, Cancun (2010). United Nations Climate Change Summit https://unfccc.int/meetings/cancun_nov_2010/meeting/6266.php

United Nations Climate Change Summit, Durban (2011). United Nations Climate Change Summit https://unfccc.int/meetings/durban_nov_2011/meeting/6245.php

United Nations Economic and Social Development Local Agenda 21 (1992).

United Nations Human Development Index (2003). A compact among nations to end poverty. UNDP. New York. Oxford University Press.

United Nations. (2011). 'The Millennium Goals Report' http://www.aidsdatahub.org/en/whatsnew/287-all-data-alerts/728-the-millennium-development-goals-report-2011-unitednations-2011 Accessed July 19th, 2011.

United Nations.(1993). 'Integrated Environmental and Economic Accounting: Handbook of National Accounting: Studies in Methods', Series F. No 61, Department for Economic and Social Information and Policy Analysis, Statistical Division, United Nations, New York.

Urry, J. (2010). 'Consuming the planet to excess'. Theory, Culture and Society.. 27 191-212

Veletsianos, G. and Kimmons, R. (2011). 'Networked Participatory Scholarship: Emergent technocultural pressures toward open and digital scholarship in online networks' In Computers \& Education Elservier 58. 766-774.

Vickers, G., (1983). 'Human Systems are Different', Harper and Row, London.

Villalba, C. and Romiszowski, A.J. (2001). 'Current and ideal practice in designing, developing and delivering web-based training', In Khan, B.H. (ed) Web-based Training, Englewood Cliff, NJ: ETP, p. 325-342

Wadsworth, Y. (2010). 'Building in Research and Evaluation.Human Inquiry for living systems'. Allen and Unwin. Sydney

Wenger, E, White, N. and Smith, J. (2009). 'Digital Habitats: stewarding technology for communities'. CP Square, Portland.

Wenger, E., (1998). 'Communities of Practice'.Cambridge University Press.

Wilkinson, R. and Pickett, K. (2009). 'The Spirit Level'. London. Allen Lane

Young, I.M. (2000). 'Inclusion and democracy'. Oxford. Oxford University Press. 